\title{
Sulphur Supply Level Effects on the Assimilation of Nitrate and Sulphate into Amino Acids and Protein in Forage Rape (Brassica napus L.)
}

\author{
Bok-Rye Lee and Tae-Hwan Kim
}

BK21 Research Team for the Control of Animal Hazards using Biotechnology, College of Agriculture

\& Life Science, Chonnam National University, Gwangju 500-757, Korea

\begin{abstract}
Sulphur deficiency has become widespread over the past several decades in most of the agricultural area. Oilseed rape (Brassica napus L.) is a very sensitive to S limitation which is becoming reduction of quality and productivity of forage. Few studies have assessed the sulphur mobilization in the source-sink relationship, very little is known about the regulatory mechanism in interaction between sulphur and nitrogen during the short-term sulphur deficiency. In this study, therefore, amount of sulphur and nitrogen incorporated into amino acids and proteins as affected by different S-supplied level (Control: $1 \mathrm{mM} \mathrm{SO}_{4}{ }^{2-}$, S-deficiency: $0.1 \mathrm{mM} \mathrm{SO}_{4}{ }^{2-}$, and S-deprivation: $0 \mathrm{mM} \mathrm{SO}_{4}{ }^{2-}$ ) were examined. The amount of sulphur in sulphate (S-sulphate) was significantly decreased by $25.8 \%$ in S-deprivation condition, compare to control, but not nitrogen in nitrate (N-nitrate). The markedly increase of sulphur and nitrogen incorporated amino acids (S-amino acids and $\mathrm{N}$-amino acids) was observed in both S-deficiency and S-deprivation treatments. The amount of nitrogen incorporated proteins ( $\mathrm{N}$-protein) was strongly decreased as sulphur availability while the amount of sulphur incorporated into proteins (S-protein) was not affected. A highly significant (p $\leq 0.001$ ) relationship between S-sulphate and S-amino acid was observed whereas the increase of $\mathrm{N}$-amino acids is closely associated with decrease of N-proteins. These data indicate that increase of sulphur and nitrogen incorporated into amino acids was from different nitrogen and sulphur metabolites, respectively.

(Key words : Amino acid, Brassica napus, Nitrate, Proteins, Sulphate, Sulphur deficiency)
\end{abstract}

\section{I . INTRODUCTION}

Sulphur in higher plants is essential microelements. It is component for the synthesis of amino acids cysteine and methionine, in coenzymes, sulfolipids, sulfosaccharides and in many S-containing secondary compounds. Sulphur is taken by roots and first activated to adenosine 5'-posphosulphate (APS) catalyzed by ATP sulphury- lase (ATPS). In plants, APS is reduced to sulfite by APS reductase (Kopriva et al., 2002). Sulfite reduced to sulfide which is incorporated by o-acetylserine (thiol) lyase into the amino acid accepter o-acetylserine (OAS) to form cysteine. Cysteine can be used directly for synthesis of proteins and glutathione (GSH) or serve as a donor of reduced sulphur for synthesis of methionine and various co-enzymes (Takahashi et

Corresponding author: Tae-Hwan Kim, Department of Animal Science, Institute of Agriculture Science and Technology, College of Agriculture \& Life Science, Chonnam National University, Gwangju 500-757, Korea. Tel: +82-62-530-2126, Fax: +82-62-530-2129, E-mail: grassl@ chonnam.ac.kr 
al., 2011). The tripeptide GSH is a major sulphur-containing metabolite that plays an important part in the defence mechanism against various biotic and a biotic stress conditions (Rouhier et al., 2008).

Sulphur availability has been decreasing in many areas of the world during the last two decades (McGrath et al., 1996; Zhao et al., 1999) because of reducing emission of sulphur to the atmospheres which has resulted in a consequence decrease in the atmospheric deposition of sulphur on to agriculture land (McGrath et al., 1996). It is well documented that sulphur deficiency decreased crop yields and quality, and even mild sulphur deficiency is known to influence overall plant quality (Hawkesford, 2000). Plants that exposed to sulphur deficient condition induced sulphate uptake and the rate of sulphate reduction (Maruyama-Nakashita et al., 2003; Nikiforova et al., 2003). Starvation of sulphate results in a decline in the tissue concentration of pathway end-products, cysteine, glutathione and S-adenosyl methionine (BlakeKalff et al., 1998; Lappartient, 1999), and an increase in the level of OAS (Kim et al., 1999). Moreover, this response includes increase of expression levels in several sulphate transporters and in enzyme activities related sulphur assimilation such as ATPS and APS reductase (Nikiforova et al., 2003; Lappartient et al., 1999). In addition, sulphate deficiency results in a reduction of nitrate reductase activity and in reduced protein synthesis and, therefore, in the accumulation of amino acids (Reuveny et al., 1980; Prosser et al., 2001). Therefore, a strong relationship between sulphur and nitrogen assimilation pathways has been found in wide range of plant species especially under S-starvation.

Oilseed rape (Brassica napus L.) is an ideal model to study sulphur deficiency in plants because of its high demanding for sulphur. For example, total $\mathrm{S}$ uptake in $B$. napus crops at maturity around $80 \sim 100 \mathrm{~kg} \mathrm{ha}{ }^{-1}$ (Zhao et al., 1993) compared to $15 \sim 20 \mathrm{~kg} \mathrm{ha}{ }^{-1}$ in wheat (Zhao et al., 1999). In addition, the rape produces seeds with a large yield of protein with relatively large quantities of S-containing amino acids (Blake-Kalff et al., 1998). Besides, rape plants belong to the family of catch crops which have high capability to uptake nitrate and potassium. This character makes rape plants useful to dispose the excessive $\mathrm{N}$ and $\mathrm{P}$ so as to make great contributions to the environment friendly agriculture or industry. Thus, the study on physiological significance of sulphur deficiency in rape plants will facilitate the prediction of responses to decreased sulphur inputs and may provide useful diagnostic indicators of sulphur status. Most of sulphate taken up by roots is stored in vacuoles of mesophyll cells and is mobilized from these storage compartments if it required (Bell et al., 1995). Blake-Kalff et al. (1998) reported that under optimal sulphur supply, $70 \sim 90 \%$ of the total sulphur in middle and oldest leaves accumulated as sulphate which is the major sources of sulphur during the sulphur deficiency. Phenotypically, the first visible S starvation symptom occurs on young leaves, which constitute the main sink organ for newly acquired sulphate (Anderson, 2005), because of reduction of transport of sulphate from root to young leaves throughout xylem (Clarkson and Hawkesford, 1993; Anderson, 2005). Additionally, remobilization of sulphur in old leaves occurred 
to support sulphur to development or young leaves during the sulphur deficiency conditions.

Although sulphur mobilization in the sourcesink relationships have already been described, very little is known about the regulatory mechanism in interaction between sulphur and nitrogen partitioning during the sulphur limitation. As a consequence, $\mathrm{N}$ and $\mathrm{S}$ content in nitrate, sulphate, amino acid, and protein were quantified to investigate partitioning of sulphur and nitrogen in old leaves of Brassica napus.

\section{MATERIALS AND METHODS}

\section{Plant culture}

Seeds of rape (Brassica napus L. cv. Mosa) were germinated in the bed soil which contained 14 19\% peatmoss, 8 12\% perlite, 67 73\% cocopeat and $5 \sim 9 \%$ zeolite at $25^{\circ} \mathrm{C}$ in the dark. The seedlings at the growth stage of three leaves were transferred on hydroponic culture $3 \mathrm{~L}$ plastic pots. The seedlings were grown in a greenhouse with day/night mean temperature $27 / 20^{\circ} \mathrm{C}$. Natural light was supplemented by metal halide lamps and sodium lamps that

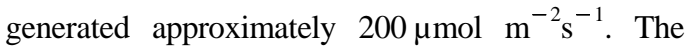
basic nutrient solution contained $1.0 \mathrm{mM}$ $\mathrm{NH}_{4} \mathrm{NO}_{3}, \quad 0.5 \mathrm{mM} \quad \mathrm{KH}_{2} \mathrm{PO}_{4}, \quad 1.5 \mathrm{mM} \quad \mathrm{CaCl}_{2}, 0.5$ $\mathrm{mM} \quad \mathrm{MgSO}_{4}, \quad 1.5 \mathrm{mM} \quad \mathrm{K}_{2} \mathrm{SO}_{4}, 0.2 \mathrm{mM} \quad \mathrm{Fe}-\mathrm{Na}$ EDTA, $\quad 14 \mu \mathrm{M} \quad \mathrm{H}_{3} \mathrm{BO}_{3}, \quad 5.0 \mu \mathrm{M} \quad \mathrm{MnSO}_{4} \cdot \mathrm{H}_{2} \mathrm{O}$, $3.0 \mu \mathrm{M} \quad \mathrm{ZnSO}_{4} \cdot 7 \mathrm{H}_{2} \mathrm{O}, \quad 0.7 \mu \mathrm{M} \quad \mathrm{CuSO}_{4} \cdot 5 \mathrm{H}_{2} \mathrm{O}$, $0.7 \mu \mathrm{M}\left(\mathrm{NH}_{4}\right)_{6} \mathrm{Mo}_{7} \mathrm{O}_{24}$ and $0.1 \mu \mathrm{M} \quad \mathrm{CoCl}_{2}$. This basic nutrition solution was continuously aerated and renewed every $5 \mathrm{~d}$. Eight-week-old plants with good uniformity were selected for the treatments.
The control plants were exposed to complete nutrient solution (1.0 $\left.\mathrm{mM} \mathrm{SO}_{4}{ }^{2-}\right)$. For S-deficient $\left(0.1 \mathrm{mM} \mathrm{SO}_{4}{ }^{2-}\right)$ and S-deprivation $\left(0 \mathrm{mM} \mathrm{SO}_{4}{ }^{2-}\right)$ treatments, $\mathrm{SO}_{4}{ }^{2-}$ concentration in the nutrient solution was decreased to $0.1 \mathrm{mM}$ or withdrawn $\mathrm{SO}_{4}{ }^{2-}$ source from the control solution with controlling cation/anion balance. Three plants per treatment were harvested at $25 \mathrm{~h}$ after treatment. Each plant was separated into old leaves, middle leaves, young leaves, and roots. We used only old leaves for this experiment.

\section{Chemical fractionation}

Two hundred milligrams of finely ground freeze-dried samples were extracted twice with $100 \mathrm{mM}$ sodium-phosphate buffer $(\mathrm{pH} \quad 7.5)$ at $4^{\circ} \mathrm{C}$. Proteins in the combined supernatant were precipitated with $80 \%(\mathrm{v} / \mathrm{v})$ acetone and centrifuged at $10,000 \mathrm{~g}$ at $4^{\circ} \mathrm{C}$ for $10 \mathrm{~min}$. The resultant pellets, which corresponded to the soluble protein fractions, were re-suspended in $0.5 \mathrm{~mL}$ of extraction buffer. $\mathrm{NO}_{3}{ }^{-}$and amino acids in the soluble fraction were further separated through a Dowex $50 \mathrm{H}^{+}$column, as described by Kim et al. (2004). The aliquot obtained after protein precipitation was evaporated under vacuum at $4^{\circ} \mathrm{C}$, precipitated with $95 \%$ ethanol at $-20^{\circ} \mathrm{C}$, and centrifuged. The resultant supernatant was passed through an $\mathrm{H}^{+}$column (Dowex 50W $\times 8$ ). The $\mathrm{pH}$ of solution collected from the $\mathrm{H}^{+}$ column was adjusted to neutral $\mathrm{pH}$, and this solution was concentrated to a final volume of $0.5 \mathrm{~mL}\left(\mathrm{NO}_{3}{ }^{-}\right.$and $\mathrm{SO}_{4}{ }^{2-}$ fraction). The amino acids were eluted from the Dowex $50 \mathrm{~W} \times 8$ columns with $25 \mathrm{~mL}$ of $0.5 \mathrm{~N} \mathrm{HCl}$ and concentrated to $1 \mathrm{~mL}$. For the fractionated liquid 
samples, an appropriate sample volume (usually $0.1 \mathrm{~mL}$ ) containing more than the minimum quantity (25 $\mu \mathrm{g} \quad \mathrm{N})$ was dropped into a tin capsule that was cooled with liquid nitrogen. The contents of the tin capsules were then freeze-dried.

\section{Statistical analysis and presentation of data}

Three treatments were completely randomized design with three replicates. An individual pot containing three plants represented a replicate. Doncan's multiple range test was employed to compare the means of separate replicates by using software SAS (version 9.1). Regression analysis was also applied to determine the significance of relationships among the measured variables.

\section{RESULTS}

1. Amount of $S$ and $N$ in sulphate and nitrate fraction

The amount of $\mathrm{S}$ in sulphate (S-sulphate) and $\mathrm{N}$ in nitrate (N-nitrate) fraction was estimated after $25 \mathrm{~h}$ applying of three different level of sulphur in old leaves of Brassica napus (Fig. 1). In control plants $\left(1 \mathrm{mM} \mathrm{SO}{ }^{2-}\right)$, the amount of S-sulphate was $2,577 \mu \mathrm{g} \mathrm{g}^{-1}$ DW. The Ssulphate is significantly decreased by $13.8 \%$ and

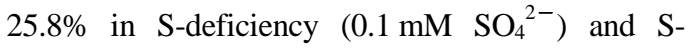
deprivation $\left(0 \mathrm{mM} \mathrm{SO}_{4}{ }^{2-}\right)$ treatments, respectively, compare to control plants (Fig. 1A). On the other hand, the amount of N-nitrate was similar at three different levels of sulphur treatments

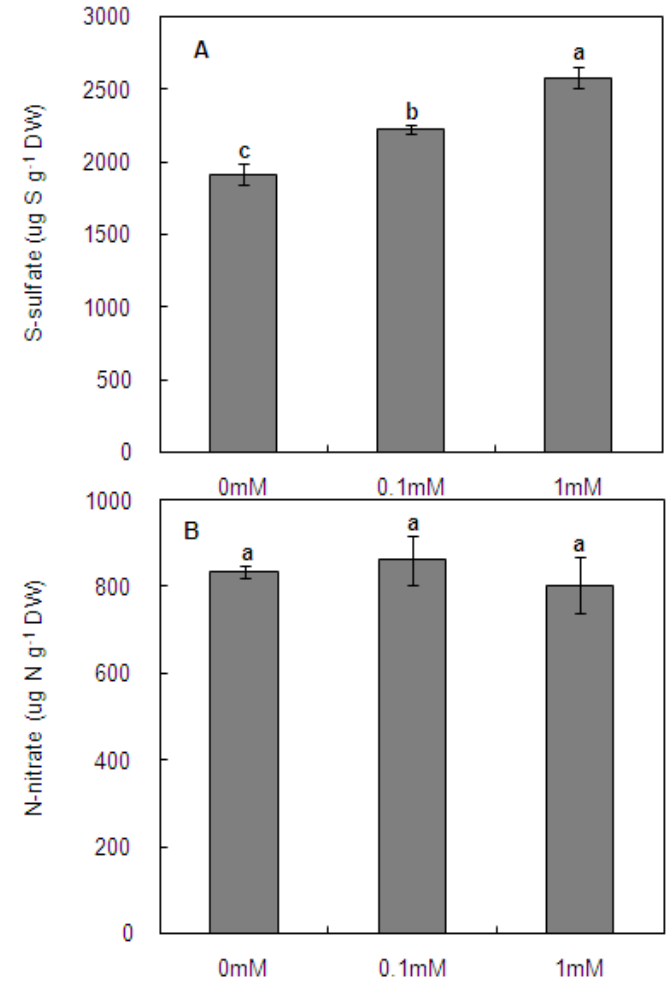

Fig. 1. Changes of amount of $S$ in sulphate (A) and $\mathrm{N}$ in nitrate (B) in old leaves after $25 \mathrm{~h}$ of treatment (S-deprivation, $0 \mathrm{mM} \mathrm{SO}{ }_{4}{ }^{2-} ;$ S-deficiency, $0.1 \mathrm{mM}$ $\mathrm{SO}_{4}{ }^{2-}$; control, $1.0 \mathrm{mM} \mathrm{SO}_{4}{ }^{2-}$ ). The vertical bars indicate $\pm \mathrm{SE}(n=3)$ when larger than the symbol. Bars labelled with different letters are significantly different ( $p>0.05$ ) according to Duncan's multiple range test.

(Fig. 1B). These results showed that $\mathrm{N}$-nitrate was not affected by short-term sulphurdeficiency.

2. Amount of $\mathrm{S}$ and $\mathrm{N}$ incorporated into amino acids and protein fraction

The effects of sulphur deficiency on amino acids and protein concentration in old leaves are presented in Fig. 2 and Fig 3. 


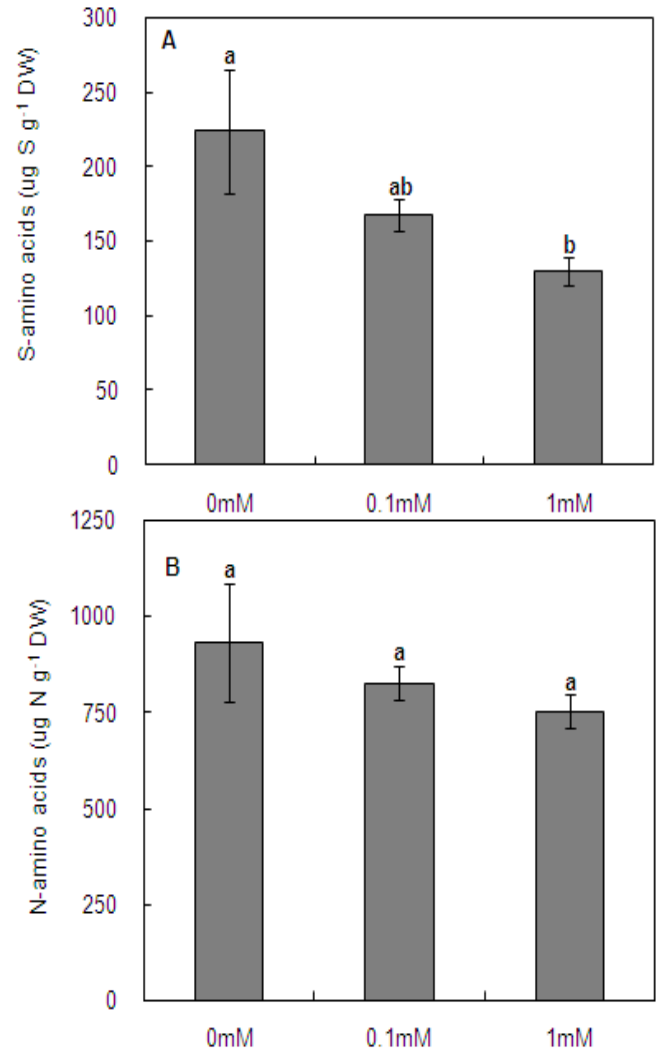

Fig. 2. Changes of amount of $S(A)$ and $N$ (B) incorporated amino acids in old leaves after $25 \mathrm{~h}$ of treatment (Sdeprivation, $0 \mathrm{mM} \mathrm{SO}_{4}{ }^{2-}$; S-deficiency, $0.1 \mathrm{mM} \mathrm{SO}_{4}{ }^{2-}$; control, $1.0 \mathrm{mM} \mathrm{SO}_{4}{ }^{2-}$ ). The vertical bars indicate $\pm \mathrm{SE}(\mathrm{n}=3)$ when larger than the symbol. Bars labelled with different letters are significantly different $(p>0.05)$ according to Duncan's multiple range test.

The sulphur limitation significantly induced amount of $\mathrm{S}$ incorporated into amino acids (Samino acids) and amount of $\mathrm{N}$ incorporated into amino acids (N-amino acids). Compare to control plants, amount of S-amino acids is increased by $72 \%$ and $33 \%$ in S-deficiency and S-deprivation treatments, respectively (Fig. 2A). The amount of $\mathrm{N}$-amino acids in S-deficiency treatment was slightly increased but it was not different with

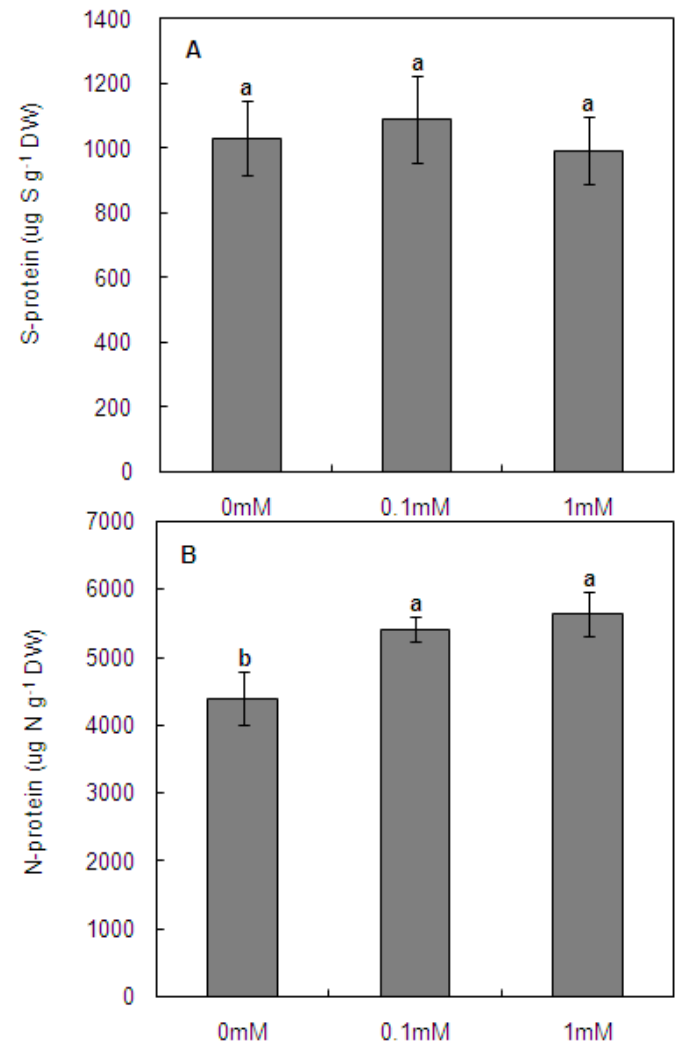

Fig. 3. Changes of amount of $S(A)$ and $N$ (B) incorporated amino acids in old leaves after $25 \mathrm{~h}$ of treatment (Sdeprivation, $0 \mathrm{mM} \mathrm{SO}_{4}{ }^{2-}$; S-deficiency, $0.1 \mathrm{mM} \mathrm{SO}_{4}{ }^{2-}$; control, $1.0 \mathrm{mM} \mathrm{SO}_{4}{ }^{2-}$ ). The vertical bars indicate $\pm \mathrm{SE}(\mathrm{n}=3)$ when larger than the symbol. Bars labelled with different letters are significantly different $(p>0.05)$ according to Duncan's multiple range test.

control whereas S-deprivation remarkably induced by $24 \%$ compare to those of control (Fig. 2B). On contrast to amino acids, no difference of amount of S incorporated into protein (S-protein) between sulphur treatments observed (Fig. 3A). The amount of $\mathrm{N}$ incorporated into protein $(\mathrm{N}$ protein) was significantly decreased by $22 \%$ in S-deprivation treatment compare to control while its amount was not different as about $5521 \mu \mathrm{g}$ 
$\mathrm{g}^{-1}$ DW on average between S-deficiency and control (Fig. 3B).

3. Relationship between amino acids and protein, sulphate or nitrate

To investigate the source of increased amount of $\mathrm{S}$ - and $\mathrm{N}$-amino acid, we determined correlations between amino acids and protein, sulphate or nitrate (Fig. 4). Significant relationship between S-sulphate and S-amino acid was observed (Fig. 4A). The increase of S-amino acid was negatively relate to S-sulphate $\left(r^{2}=0.9766\right.$, $\mathrm{p}<0.001$; Fig. $4 \mathrm{~A})$. On the other hands, there is no correlation between $\mathrm{N}$-amino acid and $\mathrm{N}$ nitrate (Fig. 4B). A significant relationship with S-amino acid was not found in S-protein (Fig. 4C). In contrast, the increase of $\mathrm{N}$-amino acid is closely associated with decrease of N-protein $\left(r^{2}=0.9416, p<0.001\right.$; Fig. 4D).

\section{DISCUSSION}

The present experiment investigated early events of S-deficiency on partitioning of endogenous $\mathrm{S}$ and $\mathrm{N}$ in old leaves of rape seed, which is main organ source, as exposed to Sdeficiency or S-deprivation condition for $25 \mathrm{~h}$.

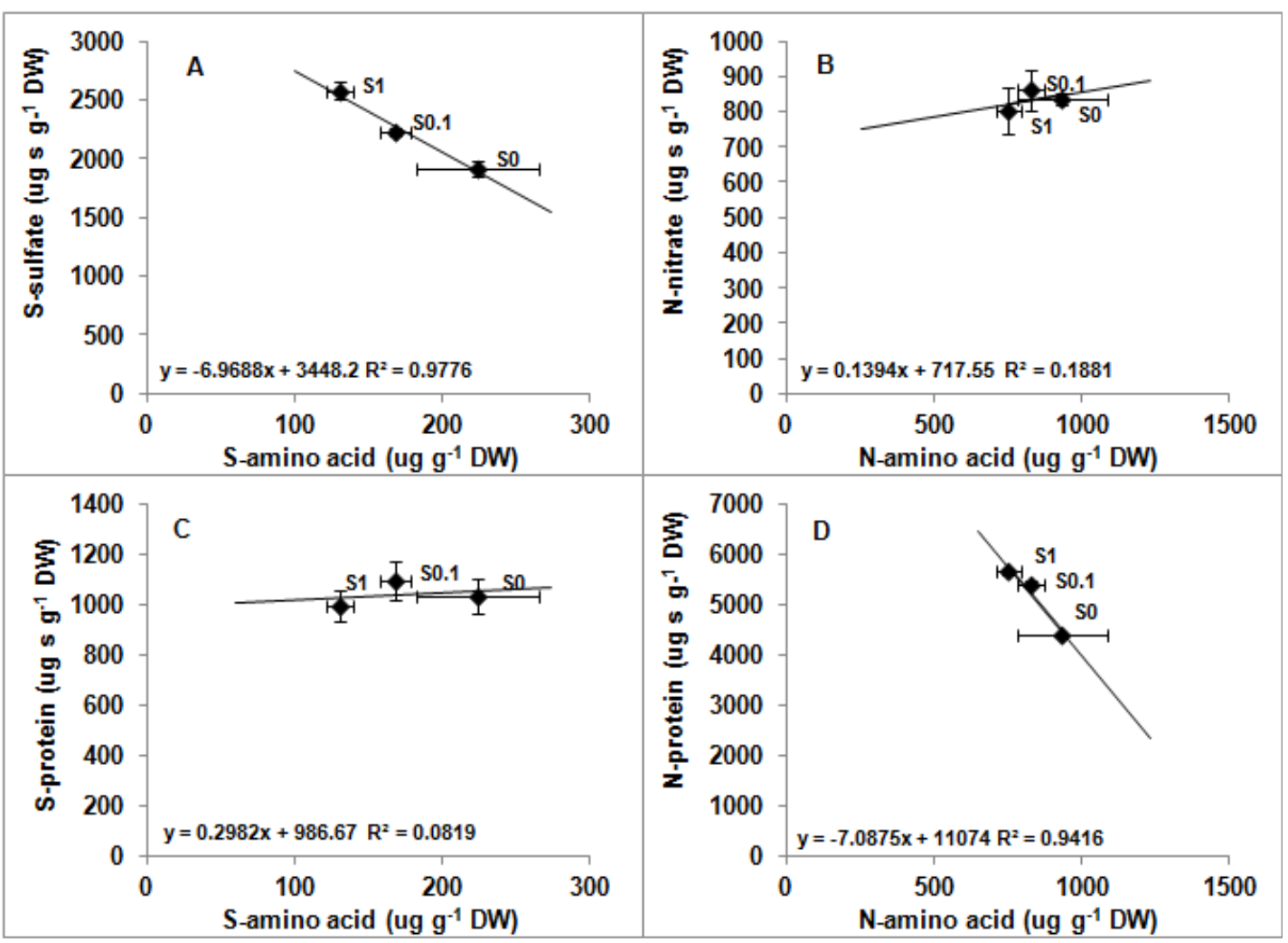

Fig. 4. The relationship between the amount of amino acids and sulphate $(A)$, nitrate $(B)$, protein $(C$ and $D)$. Value is given as mean $\pm S E$ for $n=3$ and numbers with each symbol indicate the different concentration of sulphur. Significant levels of the liner correlation coefficient were donated by *, **, and *** for $\mathrm{p}<0.05, \mathrm{p}<0.01$ and $\mathrm{p}<0.001$. 
The observed changes in amount of S-sulphate were significantly affected by S-supply levels, whereas no significant change appeared for $\mathrm{N}$ nitrate (Fig. 1). These results were accompanied by changes in sulphate and nitrate uptake which was observed previous studies ( $\mathrm{Li}$ et al., 2009). Similar results reported by Abdallah et al. (2010) that plant total $\mathrm{N}$-content or $\mathrm{N}$-uptake was not affected by sulphate limitation. According to Hawkesford and De Kok (2006), in response to a limitation of $\mathrm{S}$ availability, the hypothetical initial responses involve optimization of S uptake and utilization of sulphate, accompanied by an increase in remobilization of inorganic $S$ reserves from vegetative tissues. It has been demonstrated recently that the efflux of sulphate from the vacuoles was catalyzed by sulphate transporter (Kataoka et al., 2004). In addition, increase of BnSultr4;1 and BnSultr4;2 transcript accumulation is highly correlated with the ${ }^{34} \mathrm{SO}_{4}{ }^{2-}$ movement in old leaves of Brassica napus (Dubousset et al., 2009). Although transcription of sulphate transporter gene in vacuoles is increased, the amount of sulphate remobilized from old leaves to young leaves is extremely small. The sulphate remobilized from the vacuoles, therefore, is metabolized to transportable forms of sulphur containing compounds as thiols before entering source- to sink transport system (Takahashi et al., 2011).

On the other hands, increase of sulphur during the sulphur deficiency was not only from sulphate reserved but also existing proteins. It has been demonstrated that sulphur deficiency results decrease of protein synthesis following by increase of amino acid accumulation (Blake-Kalff et al., 1998). Amino acid accumulated was directly involved in serving as an energy source or a nitrogen source during limited growth and photosynthesis, detoxification of excess ammonia under periods of stress, and stabilization of enzymes and/or membranes (Kim et al., 2004). We found, in this study, that amount of amino acids was significantly increased with decreasing sulphur level (Fig. 2). Moreover, a significant reduction of amount of $\mathrm{N}$-protein was observed (Fig. 3B). These results supported by previous work (Lee et al., 2005) which increase of amino acid pool caused by water deficient stress in a transient adaptive response occurring during the first few days in relation to depression of de novo protein synthesis. It is not surprising that protein content is decreased by sulphur starvation because protein is consistent with the relatively stable $\mathrm{S}$ to $\mathrm{N}$ molar ration of 1:25 (Rennenberg, 1984). Besides, it has been long known that a deficiency for one element represses the other pathway. In various systems, APR expression and activity was shown to be down-regulated by nitrogen starvation (Yamaguchi et al., 1999). In contrast, sulphur deficiency results in a reduction of nitrate reductase activity and accumulation of amino acids (Reuveny et al., 1984). As expected, highly negative correlation was observed between amount of $\mathrm{N}$ protein and $\mathrm{N}$-amino acids. However, there was any relationship between amount of S-protein and S-amino acids (Fig. 4). In the present study there was no evidence for the export of $\mathrm{S}$ protein from old leaves of B.napus exposed to sulphur stress (Fig. 3A). These results are supported by Sunarpi and Anderson (1996, 1997a, b) finding $\mathrm{S}$ from protein in mature leaves remained constant regardless of the level of $\mathrm{S}$ 
nutrition. Additionally, they found that $\mathrm{N}$ stress promotes an increase in the redistribution of $\mathrm{SO}_{4}{ }^{2-}$ from older leaves (Sunarpi and Anderson, 1997a) and stimulates the hydrolysis of proteins and the subsequent export of $\mathrm{S}$ from protein (Sunarpi and Anderson, 1997b). It might be Sulphur from protein is not easily occurred hydrolysis during short-term sulphur deficiency but not in nitrogen stress.

On the other hand, strong relationship was observed between S-amino acid and S-sulphate (Fig. 4A). As most of sulphur in old leaves was stored as sulphate, it served sulphur source during the sulphur stress (Blake-Kalff et al., 1998). Therefore, these data indicate that increase of sulphur incorporated into amino acid caused by sulphur deficiency might be associated with the reduction of sulphate in old leaves. As a consequence, these data indicate that increase of sulphur and nitrogen incorporated into amino acids are from different nitrogen and sulphur metabolites, respectively, during the short-term sulphur deprivation.

\section{ACKNOWLEDGEMENT}

This work was supported by the Korea Research Foundation Grant funded by the Korean Government [KRF-2008-357-F00031].

\section{REFERENCE}

Abdallah, M., Dubousset, L., Meuriot, F., Etienne, P., Avice, J.C. and Ourry, A. 2010. Effect of mineral sulphur availability on nitrogen and sulphur uptake and remobilization during the vegetative growth of Brassica napus L. Journal of
Experiment Botany. 61:2335-2346.

Anderson, J.W. 2005. Regulation of sulphur distribution and redistribution in grain plants. In: K. Saito, I. De KokStulen, M.J. Hwkesford, E. Schung, A. Sirko, H. Rennenberg (eds). Sulphur Transport and Assimilation in Plants in the Postgenomic Era. Backhys Publisher, Leiden, pp. 23-31.

Bell, C.I., Clarkson, D.T. and Cram, W.J. 1995. Sulphate supply and its regulation of transport in roots of a tropical legume Macropitilium atropurpureum cv. Siratro. Journal of Experiment Botany. 46:65-71.

Blake Klaff, M.M.A., Harrison, K.R., Hawkes- ford, M.J., Zhao F.J. and McGrath, S.P. 1998. Allocation of sulphur within oilseed rape (Brassica napus L.) leaves in response to sulphur deficiency. Plant Physioloy. 118:1337-1344.

Clarkson, D.T. and Hawkesford, M.J. 1993. Molecular biological approaches to plant nutrition. Plant and Soil. 155/156:21-31.

Dubousset, L., Abdallah, M., Desfeus, A.S., Etienne, P., Meuriot, F., Hawkesford, M.J., Gombert, J., Ségura, R., Bataillé, M.-P., Rezé, S., Bonnefoy, J., Ameline, A.F., Ourry, A., Le Dily F. and Avice, J.C. 2009. Remobilization of leaf S compounds and senescence in response to restricted sulphate supply during the vegetative stage of oilseed rape are affected by mineral $\mathrm{N}$ availability. Journal of Experimental Botany. 60: 3239-3253.

Hawkesford, M.J. 2000. Plant responses to sulphur deficiency and the genetic manipulation of sulphate transporters to improve S-utilization efficiency. Journal of Experimental Botany. 51: 131-138.

Hawkesford, M.J. and De Kok, L.J. 2006. Managing sulphur metabolism in plants. Plant, Cell and Environment. 29:382-395.

Kataoka, T., Watanabe-Takahashi, A., Hayashi, N., Ohnishi, M., Mimura, T., Buchner, P., Hawkesford, M.J., Yamaya, T. and Takahashi, H. 2004. Vacuolar sulphate transporters are essential 
determinants controlling internal distribution of sulphate in Arabidopsis. Plant Cell 16:2693-2704.

Kim, H., Hirai, M.Y., Hayashi, H., Chino, M., Naito, S. and Fujiwara, T. 1999. Role of Oacetyl-L-serine in the coordinated regulation of the expression of a soybean seed storage-protein gene by sulfur and nitrogen nutrition. Planta. 209: 282-289.

Kim, T.H., Lee, B.R., Jung, W.J., Kim, K.Y., Avice, J.C. and Ourry, A. 2004. De novo protein synthesis in relation to ammonia and proline accumulation in water stressed white clover. Functional Plant Biology. 31:847-855.

Kopriva, S., Suter, M., von Ballmoos, P., Hesse, H., Krähenbühl, U., Rennenberg, H. and Brunold, C. 2002. Interaction of sulphate assimilation with carbon and nitrogen metabolism in Lemna minor. Plant Physiology. 130:1406-1413.

Lappartient, A.G., Vidmar, J.J., Leustek, T., Glass, A.D.M. and Touraine, B. 1999. Inter-organ signaling in plants: regulation of ATP sulfurylase and sulphate transporter genes expression in roots mediated by phloem-translocated compound. Plant Journal. 18:89-95.

Lee, B.R., Jung, W.J., Kim, K.Y., Avice, J.C., Ourry, A. and Kim, T.H. 2005. Transient increase of de novo amino acid synthesis and its physiological significance in water-stressed white clover (Trifolium repens). New Phytologist 182: 654-663.

Li, Y., Gao, Y.X., Ding, L., Shenand, Q.R. and Guo, S.W. 2009. Ammonium enhances the tolerance of rice seedlings (Oryza sativa L.) to water stress. Agricultural Water Management. 96:1746-1750.

Maruyama-Nakashita, A., Inoue, E., WatanabeTakahashi, A., Yamaya, T. and Takahashi, H. 2003. Transcriptome profiling of sulphur responsive genes in Arabidopsis reveals global effects of sulphur nutrition on multiple metabolic pathways. Plant Physiology. 132:597-605.

McGrath, S.P. and Zhao, F.J. 1996. Sulfur uptake, yield response and the interaction between nitrogen and sulfur in winter oilseed rape
(Brassica napus). The Journal of Agricultural Science. 126:53-63.

Nikiforova, V., Freitag, J., Kempa, S., Adamik, M., Hesse, H. and Höfgen, R. 2003. Transcriptome analysis of sulfur depletion in Arabidopsis thaliana: interlacing of biosynthetic pathways provides response specificity. Plant Journal. 33: 633-650.

Prosser, I.M., Purves, J.V., Saker, L.R. and Clarkson, D.T. 2001. Rapid disruption of nitrogen metabolism and nitrate transport in spinach plants deprived of sulphate. Journal of Experimental Botany. 52:113-121.

Rennenberg, H. 1984. The fate of excess sulphur in higher plants. Annual Review of Plant Physiology. 35:121-153.

Reuveny, Z., Dougall, D.K. and Trintity, P.M. 1980. Regulatory coupling of nitrate and sulphate assimilation path ways in cultured Tobacco cells. Proceedings of the National Academy of Sciences 77:6670-6672.

Rouhier, N., Lemaire, S.D. and Jacquot, J.P. 2008. The role of glutathione in photosynthetic organisms: emerging functions for glutaredoxins and glutathionylation. Annual Review of Plant Biology. 59:143-166.

Sunarpi and Anderson, J.W. 1996. Distribution and redistribution of sulphur supplied as $\left[{ }^{35} \mathrm{~S}\right]$ sulphate to roots during vegetative growth of soybean. Plant Physiology. 110:1151-1157.

Sunarpi and Anderson, J.W. 1997a. Effect of nitrogen nutrition on remobilization of protein sulfur in the leaves of vegetative soybean and associated changes in soluble sulfur metabolites. Plant Physiology. 115:1671-1680.

Sunarpi and Anderson, J.W. 1997b. Effect of nitrogen nutrition on the export of sulfur from leaves in soybean. Plant and Soil 188:177-187.

Takahashi, H., Kopriva, S., Giordano, M., Saito, K. and Hell, R. 2011. Sulfur assimilation in photosynthetic organisms: molecular functions and regulations of transporters and assimilatory 
enzymes. Annual Review of Plant Biology. 62: 157-184.

Yamaguchi, Y., Nakamura, T., Harada, E., Koizumi, N. and Sano, H. 1999. Differential accumulation of transcripts encoding sulfur assimilation enzymes upon sulfur and/or nitrogen deprivation in Arabidopsis thaliana. Bioscience, Biotechnology, and Biochemistry. 63:762-766.

Zhao, F.J., Evans, E.J., Bilsborrow, P.E. and Syers,
J.K. 1993. Influence of $\mathrm{S}$ and $\mathrm{N}$ on seed yield and quality of low glucosinolate oilseed rape (Brassica nepus L.). Journal of Science of Food and Agriculture. 63:29-37.

Zhao, F.J., Hawkesford, M.J. and McGrath, S.P. 1999. Sulphur assimilation and effects on yield and quality of wheat. Journal of Cereal Science. 1:1-17.

(Received October 6, 2012/Accepted November 14, 2012) 